\title{
Ønsket om å lindre smerte, ønsket om å forhindre smerte
}

Jeg tror at de aller fleste som går inn i helsevesenet, som blir leger, har disse to ønskene sterkt i seg - ønsket om å lindre og ønsket om å forhindre (ytterligere) smerte. Og jeg tror at det da kan føles vondt - og til og med provoserende - at jeg som selvskader har forårsaket mye av min egen smerte selv. Sånn som noen ser det, uten der og da å forstå at uten kuttene ville smerten min vært økt, forhøyet, at uten kuttene ville smerten vært så stor at jeg kanskje ikke hadde holdt ut mer, ikke greid å leve videre. Det kan være vanskelig å innse - se inn i at lidelsen for meg ville ha vært mye større hvis jeg ikke hadde kuttet meg selv. Kuttet var for meg et resultat av nettopp dette ønsket om å lindre.

\section{Jeg trenger hjelp}

«Hvis noen hadde gjort det du gjør mot deg selv, ville det ha vært straffbart», var det en som sa til meg en gang. For ja, det er en krenkelse mot kroppen. Og loven fastslår ved overtredelser at det ikke skal være sånn, det må få konsekvenser for den utøvende part. Men se, jeg er begge parter. Og jeg trenger ikke å få reprimander, jeg vet utmerket godt at jeg ikke skulle ha gjort det, at jeg skulle ha bedt om hjelp på andre måter, jeg vet jo det. Men jeg trenger ikke kjeft og innett banning, dårlige skjulte sukk over en umulig situasjon. Det jeg trenger, er «Hvorfor skjedde dette nå? Er det noe jeg kan gjøre, annet enn å sy deg?» Det jeg trenger, er nettopp lindring. Og ikke nye episoder i skam. Når jeg er blitt møtt med en ærlig usikkerhet, en ærlig medfølelse, hvor mye i meg er vel ikke blitt helere ved det? Men så sier noen, ganske mange: «sekundærgevinst, søk å eliminere sekundærgevinst.» Men jeg sier: Hvordan er det mulig å tro at litt respekt og interesse på mine vegne er skadelig for meg?

Jeg sier det rett ut, det var det motsatte som var tilfellet. Det var når jeg ikke fikk noen som helst trøst at jeg kom igjen etter et kvarter. Sårene betydde: Jeg trenger hjelp. Men jeg greide ikke å spørre. Og hva er så galt med å like en behandlende lege, til og med oppsøke en behandlende lege flere ganger hvis denne legen har gitt litt ekstra trøst? Er det ikke et helt ufattelig fremskritt - ikke å ville være i ensomheten lenger. Og jeg forstår jo uten vanskeligheter at dette er en ganske uheldig måte å be om hjelp på. Som mine behandlere har sagt og sagt til meg, det er ikke sånn det behøver å være. Men det er i alle fall et første forsøk på å si ifra på en bedre måte senere: «Dette er for vondt. Noen må hjelpe meg, vær så snill, noen må hjelpe meg.» Det å ønske andre inn, det er et fremskritt.

\section{Det er ditt valg}

Innleggelse ved tvang skjer, så vidt jeg vet, ved ordene «til fare for seg selv eller andre». Men å være innlagt lenge (når jeg var suicidal) var for meg å bli mer til fare for meg selv. Hvis jeg bare gikk der, lenge i det vonde, ville jeg jo bare mer og mer dø, og ikke mindre. Jeg har fått veldig mye ut av de låste dørene og all hjelpen på akuttposten, men jeg hadde kanskje ikke levd nå, hvis jeg ikke også hadde hatt opplevelser der jeg sterk og glad tenkte: Herregud, dette her vil jeg oppleve mer av.

\section{«Og så har jeg fått hjelp. Helt ubeskrivelig god hjelp, varig hjelp. Jeg har fått lindring»}

Men setningen - «Det er ditt valg. Jeg kan $i k k e$ forhindre deg hvis du virkelig vil (dø)» - har vært vond å høre. For meg betydde den: Jeg vil ikke forhindre deg. Bare gjør det, det er denne fomlingen jeg ikke liker, gjør det skikkelig. Det fikk meg gang på gang til å tippe forferdelig over. For meg var ikke valget særlig tydelig. Jeg eide omtrent ikke krefter til å ta særlig gjennomtenkte valg. For meg var dette «vil» både en vilje og en verbform, futurum: Det vil skje uansett. Men det å få denne setningen uttrykt, verbalisert av legen/den andre parten hjalp meg ikke. Det var det motsatte som skjedde, det fikk «futurumen» til å rykke nærmere presens, nåtiden. Å presse meg var å presse meg til bare å gi opp, gi etter. Det var nærmest ingen krefter å gå på.

\section{Lindring}

Og så har jeg fått hjelp. Helt ubeskrivelig god hjelp, varig hjelp. Jeg har fått lindring.

Lindring - av ord: «Oj, det der ser ikke godt ut.», «Jeg har tenkt på deg, hvordan det går med deg?» Lindring - ved å få sydd såret. For å forhindre ytterligere smerte er jeg blitt bedøvd og sydd grundig, slik at det ikke skulle sprekke opp og begynne å silblø. Lindring - ved at såret er blitt fint sydd. (Ja, jeg brydde meg ikke i det hele tatt om det der og da, men nå synes jeg det er leit å se ut sånn.)

Lindring - ved ikke å gi meg følelsen av at jeg krever for mye, at jeg opptar tiden for de som er «virkelig» syke, at behandlingen av meg ikke er unødvendig bruk av tid, men livsviktig bruk av tid, for meg. Jeg lever ennå, fordi så mange har brukt tid på meg.

Lindring - ved å si: «Jeg vil ikke at du skal være alene i natt.» Lindring - ved å spørre: «Har du tillit til behandleren din?» og «Men får du ikke noe hjelp der?» Lindre - ved setningene: «Jeg har virkelig vondt av deg.», «Jeg håper det går bedre med deg.» og «Jeg vet ikke hva jeg skal gjøre for deg, men jeg vil gjerne.»

Jeg er blitt pushet. Pushet ut av døren, ut til livet utenfor sykehus, pushet til gode opplevelser, ikke bare vonde, sånn at jeg sakte kunne få en motvekt til motløsheten. Men det å bli pushet på valg - leve/dø - er også vondt. Å bli pushet på valg var for meg ikke å bli pushet i forhold til ansvar, det var ikke sånn jeg forsto denne setningen. Det var å dytte meg over vippepunktet: «Må du, så må du.» En mulighet da er opplagt å gå mot døden, gå til det jeg ser på som opphør av smerte. En annen mulighet er å bli urolig stående på midten av vektstangen, bli stående i smerten (som ikke er til å holde ut), som er nødt til å tippe, i den ene eller andre retningen. Den tredje muligheten er å gå mot livet, bort fra vippepunktet, mot noe godt som kan komme. Men da må noen ha vist meg at det kan finnes noe godt, hvordan det gode i godt kan være. Og det skjer gjennom å lindre, gjennom medfølelse, å gi meg noe fint, noe «inni kroppen». Med så mange lindringer er det sannsynligvis, for flere enn meg, ikke lenger et så stort behov for hjelp til å forhindre. Og jeg, nå? Jeg trenger ikke lenger så mange hindringer. Jeg har fått lindringer. Jeg har fått noe inni meg. Noe som jeg vil ta vare på.

\section{Kristin Ribe}

kristin_ribe@hotmail.com

Trondheim

Kristin Ribe (f. 1972) er filolog og forfatter i Trondheim. redaktør Erlend Hem. 